\title{
REVIEWS
}

Arleta GŁowacka ${ }^{1, B-D}$, Maja Matthews-Kozanecka ${ }^{2, A, D}$, Maciej Kawala ${ }^{3, \text { A, C, Beata Kawala }}{ }^{4, A, E, ~ F}$

\section{The Impact of the Long-Term Playing of Musical Instruments on the Stomatognathic System - Review}

${ }^{1}$ Department of Maxillofacial Orthopaedics and Orthodontics, University of Medical Science, Poznan, Poland

${ }^{2}$ Department of Social Sciences, University of Medical Science, Poznan, Poland

${ }^{3}$ Department of Dental Prosthetics, Wroclaw Medical University, Poland

4 'Department of Maxillofacial Orthopaedics and Orthodontics, Wroclaw Medical University, Poland

A - research concept and design; B - collection and/or assembly of data; C - data analysis and interpretation;

$\mathbf{D}$ - writing the article; $\mathbf{E}$ - critical revision of the article; $\mathbf{F}$ - final approval of article; $\mathbf{G}$ - other

\begin{abstract}
In this article, we have made a review of the influence of playing musical instruments on the formation of malocclusion and TMJ disorders in musicians. Primary attention was paid to the effects of wind and stringed instruments. The aim of the article was the presentation of research and opinions about this problem in the last 25 years. It is reported that long-term and repetitive playing of musical instruments, particularly stringed (violin and viola) and wind instruments can cause dysfunctions of the stomatognathic system. The impact of wind instruments was assessed in terms of the type of mouthpiece. We studied the possibility of repositioning the front teeth and reducing the width of the upper dental arch and overbite. There were also reports on the use of a specific instrument to improve the child's occlusion. Studies have also been performed on the usefulness of relaxation plates in order to improve, and even prevent, dysfunction caused by the constant stress on the same parts of the stomatognathic system. The experiments were mainly based on interviews, dental cast analyses and cephalometric analyses. Additional methods were dynamometer tests and muscle tension palpation (Adv Clin Exp Med 2014, 23, 1, 143-146).
\end{abstract}

Key words: viola and violin, wind instruments, malocclusion, TMJ dysfunction, stomatognathic system.

To study creating music requires some predisposition. Each kind of instrument is different and construction of the hand, fingers, parts of face, length of hand and even construction of the whole body are especially important. Patience and dedication are also necessary on the part of young people who begin their adventure with the instrument. Being a musician requires continuous improvement of their skills and many hours of practice. A musician should show special patience and tenacity in pursuit of his or her purpose. Playing the instrument daily and daily practice are essential in this profession. It seems to be reasonable to pay attention to long-term, repetitive force on the head, mandible and facial muscles, which may result in malocclusion and another deformation of the stomatognathic system. These defects are deviations from the ideal relationships that may cause functional or aesthetic dissatisfaction among patients. They can be caused by genetic or environmental factors $[1,2]$. The aim of this study is to assess, on the basis of the literature, the impact of long-term playing of musical instruments on the formation of malocclusions in musicians.

\section{Impact of Wind Instruments on Artist's Bite}

The impact of chronic practice on the bite has been discussed repeatedly. Birmingham University researchers studied the effects of wind instruments in occlusion. They observed 170 professional musicians between $18-57$ years of age who were selected 
among 21 classical orchestras. The musicians were divided into groups depending on the type of mouthpiece which the instruments took. People playing the drums were chosen as a control group. After an analysis of dental casts, there was no significant effect of playing wind instruments on the position of the front teeth and the development of malocclusion. However, playing instruments with large brass mouthpieces may cause lateral crossbite [2].

Wind instruments such as the trumpet, clarinet and flute work by pumping air through the mouthpiece to the instrument. The force of the air, which is blown out through the musician, acts on his front teeth and may cause a change in their position. Therefore, wind instruments can be divided into categories (divided by the type of mouthpiece). In different types of mouthpieces there are different forces. Brass instruments such as trumpet, trombone and horn (e.g. French horn) have a cup-shaped mouthpiece that the musician pushes into the mouth and letting the air flow causes vibrations that are transmitted to the mouthpiece. A characteristic feature is the lack of reeds in brass instruments. Its role is taken over by the player's mouth while pressing it to the mouthpiece. The force applied to the teeth through the mouthpiece is amplified by the voltage paragraph.

Playing woodwind instruments with a single reed (e.g. clarinet or saxophone), the mouthpiece is between the lips. It is held by the incisal edge of the lower incisors and is supported by the lower lip. Here we have direct contact of the upper incisors with the mouthpiece, and the upper lip seals the upper part. The force exerted on the teeth comes from the soft tissues and direct contact with the mouthpiece. On the other hand, while playing woodwind instruments with double reeds (e.g. oboe, bassoon), the upper and lower incisors are amortized over the lips and the mouthpiece is held in position. The tone is controlled by the voltage paragraph. In the third group of woodwinds, which is flutes, the mouthpiece is integrated with the whole, rested lightly on the lower lip and the upper has virtually no contact. The lip tension force acts on the teeth. The impact of holding the mouthpiece was checked by researchers from Sweden, who studied the effects of playing wind instruments on the position of the teeth, and found little or no effect thereof. In 62 adult subjects, they performed dental casts and cephalometric measurements. There was a small difference in the width of the upper arch, which was slightly narrower, and a similar overbite. The teeth do not change their position despite the fact that, while playing on these instruments, force acts on them. It was found that this force is balanced or runs too short [3]. Other studies have been carried out by Ingervall et al. dealing with muscle activity of the mouth and the pressure that is exerted by the lips on the teeth. Facial morphology and dentition assays were performed on professionals at the age of 19 - 55 years who played wind instruments (12 on the trumpet and 12 on the clarinet). The lip force was measured with a dynamometer. Lip muscle electromyography was measured and lip pressure was checked on the teeth at rest, while chewing, during speech, and while playing an instrument. Additionally, dental casts and cephalometric x-rays were taken. Compared to the control group, there were no significant differences in pressure and muscle activity during natural operations. The pressure exerted by the soft tissues on the teeth while playing the instrument is disproportionately greater, but there was no impact on occlusion [4]. Studies were carried out in the United Kingdom comparing the occlusions of 170 professional musicians selected from 21 orchestras. Researchers concluded that playing wind instruments does not significantly influence the position of the anterior teeth, but playing a brass instrument with a large cup-shaped mouthpiece might predispose a musician to develop lingual crossbites or lingual crossbite tendencies [5]. In the United States, scientists have discussed the possibility of using the pressure exerted by the instrument on the teeth during a game. Children aged 11-13 years who were to start a music school education were examined by an orthodontist. Their task was to recommend a suitable instrument for a child with a certain bite. The instrument was not the cause of worsening occlusion but interestingly perhaps could even improve it. In most cases, it was possible to recommend more than one instrument, especially if it was necessary to correct overjet or overbite. Playing the right instrument can help to obtain proper tooth movement [6].

\section{Impact of Violin and Related Instruments on Artist's Bite}

Other instruments that may influence the formation of craniofacial bones and malocclusion are the stringed instruments. An example is the violin, held between the arm and chin and requiring special effort and muscular development. The muscle activity can cause changes in the growth of a young person's face. This fact has been described by researchers from Finland. They studied 24 students who had played from 5 to 11 years on the violin. The research was carried out in particular on the posteroanterior and lateral cephalograms and panoramic tomograms of the jaws. In all patients, 
Table 1. Literature from the years 1989-2012 describing impact of playing instruments for stomatognathic system

\begin{tabular}{|c|c|c|c|c|c|}
\hline Place & Year & Age & Amount & Instrument & Result \\
\hline Sweden & 1987 & $19-55$ & $\begin{array}{l}12 \text { on the } \\
\text { trumpets } \\
\text { and } 12 \text { on } \\
\text { the clarinets }\end{array}$ & $\begin{array}{l}\text { wind } \\
\text { instruments }\end{array}$ & $\begin{array}{l}\text { The pressure exerted by the soft tissues on the teeth } \\
\text { while playing the instrument is disproportionately } \\
\text { greater, but there has been no impact on the occlu- } \\
\text { sion }\end{array}$ \\
\hline Sweden & 1989 & adults & 62 & $\begin{array}{l}\text { wind } \\
\text { instruments }\end{array}$ & $\begin{array}{l}\text { There was little difference in the width of the upper } \\
\text { arch, it was slightly narrower }\end{array}$ \\
\hline Finland & 1996 & $11-18$ & 31 & violin & $\begin{array}{l}\text { The intense playing an instrument may predispose to } \\
\text { the development of dysfunction in the temporoman- } \\
\text { dibular joint. }\end{array}$ \\
\hline Finland & 1997 & $\begin{array}{l}11,4- \\
18,2\end{array}$ & 24 & violin & $\begin{array}{l}\text { In all patients showed elongation of the lower part } \\
\text { of the face and the mandibular branch to the right. } \\
\text { It was also increased proclination upper and lower } \\
\text { incisors }\end{array}$ \\
\hline $\begin{array}{l}\text { United } \\
\text { States }\end{array}$ & 2004 & $11-13$ & - & all & $\begin{array}{l}\text { Playing on the right instrument can help in obtaining } \\
\text { the proper teeth movement }\end{array}$ \\
\hline Germany & 2007 & $19-49$ & 20 & $\begin{array}{l}\text { wind } \\
\text { instruments }\end{array}$ & $\begin{array}{l}\text { Perhaps the way to reduce the pain in musicians can } \\
\text { be exercise of the facial muscles used in preparing } \\
\text { to play an instrument. Aim of these exercises is to } \\
\text { strengthen the muscular control of the lips, tongue } \\
\text { and lower jaw }\end{array}$ \\
\hline $\begin{array}{l}\text { United } \\
\text { Kingdom }\end{array}$ & 2009 & $18-57$ & $\begin{array}{l}170 \text { profes- } \\
\text { sional musi- } \\
\text { cians }\end{array}$ & $\begin{array}{l}\text { wind } \\
\text { instruments }\end{array}$ & $\begin{array}{l}\text { Instruments with large brass mouthpieces may cause } \\
\text { lateral crossbite, no significant effect playing on wind } \\
\text { instruments on the position of the front teeth }\end{array}$ \\
\hline Germany & 2009 & $17-63$ & 30 & $\begin{array}{l}\text { violin } \\
\text { and wind } \\
\text { instruments }\end{array}$ & $\begin{array}{l}\text { They proposed wearing orthodontic plates to artists } \\
\text { and they found reduction in symptoms in } 80 \% \text {. }\end{array}$ \\
\hline $\begin{array}{l}\text { New } \\
\text { Zealand }\end{array}$ & 2009 & $18-27$ & 20 & piano & Pianists also grind their teeth. \\
\hline $\begin{array}{l}\text { United } \\
\text { Kingdom }\end{array}$ & 2012 & adults & $\begin{array}{l}170 \text { profes- } \\
\text { sional musi- } \\
\text { cians }\end{array}$ & $\begin{array}{l}\text { wind } \\
\text { instruments }\end{array}$ & $\begin{array}{l}\text { Playing a wind instruments does not significantly } \\
\text { influence the position of the anterior teeth, but } \\
\text { playing a brass instrument with a large cup-shaped } \\
\text { mouthpiece might predispose a musician to develop } \\
\text { lingual crossbites or lingual crossbite tendencies }\end{array}$ \\
\hline
\end{tabular}

elongation of the lower part of the face and the mandibular branch to the right was shown. The proclination of the upper and lower incisors was also increased. Muscle activity on the left is balanced by the increased muscle activity on the right side of the face in holding the violin, causing imbalances in growth in young people. Similarly, the increased incisor proclination is the result of a balance of forces between the tongue and lip muscles and the pressure of the violin on the chin [7]. The researchers were also interested in disorders of the temporomandibular joint. After examining 31 young people (11-18 years) who played the violin (via interview and orthodontic and radiographic examination of the articular condyle), pain in their joints while chewing, a sense of stiffness in the joint, clenching of the teeth, protrusion and laterotrusion to the right and the deviation of the mandible to the right while opening were found. Palpation of the temporomandibular joint showed increased muscle tension and pain at maximum opening. All these findings suggest that the intense playing an instrument may predispose the young musician to the development of dysfunctions in the temporomandibular joint [8].

\section{Conclusions}

Long-term playing of the violin and wind instruments can create craniomandibular dysfunctions. That is why professional musicians often 
complain of pain in the neck, arm, or shoulder. Scientists in Germany have decided to make an attempt to reduce these problems. They proposed wearing orthodontic plates to 30 artists. They found a reduction in symptoms of $80 \%$, confirming the value of the studies [9]. Tests of muscle tension were also carried out on pianists who underwent electromyography while playing. It was found that pianists also grind their teeth. Increased activity of the masseter and anterior temporal muscles were demonstrated, which are involved in raising the lower jaw, causing contact of the upper and lower teeth [10]. Perhaps the best way to reduce pain in musicians would be exercise of the facial muscles used in preparing to play an instrument. The aim of these exercises is to strengthen muscular control of the lips, tongue and lower jaw [11]. The case studies of people playing instruments suggest that, for some instruments such as the violin, there are changes in the growth of the bones, which can cause malocclusion. These observations suggest that the problem should be mentioned and orthodontic consultation should be proposed before starting to play an instrument. Professional musicians should be offered prophylactic relaxation plates to avoid occurring dysfunctions.

\section{References}

[1] Blackley N: History of the instrumental music program of the ACT (IMPACT). Instrumental Music Program, Canberra 2007.

[2] Grammatopoulos E: A study of the effects of playing a wind instrument on the occlusion (Master of Philosophy), University of Birmingham 2009.

[3] Rindisbacher T, Hirschi U, Ingervall B, Geering A: Little influence on tooth position from playing a wind instrument. Angle Orthod 1989, 60, 223-228.

[4] Fuhrimann S, Schüpbach A, Thüer U, Ingervall B: Natural lip function in wind instrument players. Eur J Orthod 1987, 9, 216-223.

[5] Grammatopoulos E, White AP, Dhopatkar A: Effects of playing a wind instrument on the occlusion. Am J Orthod Dentofacial Orthop 2012, 141, 138-145.

[6] Herman E: Influence of musical instruments on tooth positions. Am J Orthod 2004, 80, 145-155.

[7] Kovero O, Könönen M, Pirinen S: The effect of violin playing on the bony facial structures in adolescents. Eur J Orthod 1997, 19, 369-375.

[8] Kovero O, Könönen M: Signs and symptoms of temporomandibular disorders in adolescent violin players. Acta Odontol Scand 1996, 54, 271-274.

[9] Steinmetz A, Ridder PH, Methfessel G, Burkhard M: Professional musicians with craniomandibular dysfunctions treated with oral splints. J Craniomandibular Pract 2009, 27, 221-230.

[10] Lourenço S, Clemente M, Coimbra D, Barbosa A, Pinho J: Do pianists play with their teeth? International Symposium on Performance Science, New Zealand 2009.

[11] Schade CC: Practical Evaluation of Orofacial Myofunctional Exercises: Implications for Wind Instrument Learning. Music Performance Research 2007, 1, 47-65.

\section{Address for correspondence:}

Arleta Głowacka

Department of Maxillofacial Orthopaedics and Orthodontics

University of Medical Science

Bukowska 71

60-819 Poznań

Tel.: 618547068

E-mail: klinikaort@umed.poznan.pl

Conflict of interest: None declared

Received: 22.06 .2012

Revised: 9.08.2012

Accepted: 20.02.2014 